\title{
Germ-Line Gene Therapy: Another View
}

\section{The circumstance of this editorial}

In May of 1992, I received a call from Dr. Nelson Wivel, director of the Office of Recombinant DNA Activities, inviting me to make a presentation to the RAC regarding the subject of spontaneous and induced germ-line mutation. He explained that in the light of all the current discussion concerning germ-line gene therapy, the Committee felt it needed to inform itself concerning germ-line gene dynamics, and the subject of mutation seemed a good place to start. He was extremely careful to emphasize that this invitation in no wise implied that RAC believed germ-line therapy was imminent, but only that the time was at hand for this group to begin to consider the subject in an orderly fashion. I met with the Committee on September 14, 1992. I had had sufficient time to consider the significance of the situation; after meeting my charge, I took license to express a personal view concerning the wisdom of that distinguished Committee setting up a series of briefings of this sort at this time. I thank the Committee for the tolerance it exhibited in the face of this unexpected diversion. Dr. French Anderson was in the audience and suggested I put those thoughts (with some extensions) on record in Human Gene Therapy.

\section{A viewpoint}

My message to the Committee was clear and simple: The Committee's desire to prepare itself for future developments would under most circumstances be laudable, but for a Committee with this visibility and prestige to begin to consider the subject of germ-line therapy in an organized fashion at this time would send the wrong vibes to the scientific, ethical, and political communities. Such an action might appear to imply the belief that the Committee would be seriously considering this prospect within the terms of office of present Committee members. Given the tremendous issues at stake, and even with the utmost attempt on my part to anticipate the amazing speed of advances in the field of molecular genetics. I could not imagine serious organized discussions of this subject by such a group within the next 20 or 30 years. (Individuals will, of course, express their views as they please.)

\section{The basis for this position}

I am primarily a population geneticist. My stance stems not only from that background but also from broader philosophical considerations. The bases for the position adopted above can be briefly summarized under three headings:

1. Intellectual arrogance. The elucidation of the precise nature of our genetic material, four billion years in evolving, occurred only 40 years ago. Despite the incredible advances in molecular genetics, we still have a very limited knowledge of the anatomy of our DNA, but even less understanding of how it transacts its excruciatingly complex business. Right now the ecosystem is reeling under the impact of an intellectual arrogance which assumed unbridled license to perturb that system. We are a part of that ecosystem, the last frontier, so to speak. Is there any informed person who, surveying the current evidence of the profound consequences of precipitous human action, believes we are now ready for a serious consideration of how to mold ourselves genetically?

I am perhaps the only practicing human geneticist who ever browsed (1941) through the files of the old Eugenics Record Office in Cold Spring Harbor, standard-bearer of the eugenics movement in the 1920s and 1930s. The naïveté expressed in those records and by that movement defies characterization. I fear that two generations hence, our present-day thinking about germ-line gene therapy will appear as naive and misguided as the eugenic thinking of two generations ago.

2. The lessons of somatic cell gene therapy. Somatic cell gene therapy is scarcely off the ground, its lessons yet to be divulged, and already some wish to consider germ-line therapy. Surely there is time- - two, three decades- to monitor for all the nuances of attempts at the introduction of foreign genes into somatic cells, before turning to the germ line.

With my preoccupation with the integrity of the human germ line, I would have to urge that there is one aspect of somatic cell therapy that should have high priority, namely, meticulous testing for unanticipated germ-line intrusions of the vectored DNA. The retroviral vectors employed in such therapy have been so enfeebled that there would appear to be no risk that they will carry their therapeutic passenger gene beyond the target tissue. But what of adventitial transmission into the germ line due to passing "helper" retroviruses or contamination of the vector strain by non-enfeebled virus? The human haploid genome contains of the order of one million sequences with greater or lesser homologies to retroviruses. Some of these must represent the footprints of viruses not specifically targeted to gonadal tissues. viruses which somehow strayed into the germ line. We have absolutely no idea of the price the species paid for these footprints. What we now see are the successful survivors-not those insertions resulting in genetic defect which were eliminated through selection.

While the prospects of successful germ-line intrusion in the course of retroviral-mediated somatic cell therapy seem slim (reviewed in Cornetta et al., 1991), data to this effect are urgently needed. The use of DNA-liposome complexes for gene transfer would seem to lessen the likelihood of germ-line intrusions, and, indeed, the first relevant studies reveal no evidence that DNA-liposomal transduction was accompanied by 
uptake of plasmid DNA by gonadal tissue (Nabel et al., in press). I suggest that efforts to detect gonadal intrusion by foreign DNA should become a standard requirement for gene therapy protocols; the gene therapy techniques with least evidence for germ-line contamination should be the preferred techniques.

A balanced perspective in this situation demands we recognize that the chemotherapy of certain childhood malignancies with such known mutagens as nitrogen mustard, procarbazine, cyclophosphamide, or doxorubicin also carried the risk of the induction of germ-line mutations. To a lesser extent, this potential result also holds for radiation therapy, but here genetic risks are reduced by gonadal shielding. As a result of these therapies, a substantial number of individuals who previously would have died during childhood are now reproducing. It would be inconsistent to hold somatic cell gene therapy to higher standards than those to which the accepted modalities are held. In fact, the genetic risks accompanying such chemo- and radiation therapy are unknown. I suggest that a major genetic study of the offspring of children treated either with chemotherapy/radiation or somatic cell gene transfer is called for. The number of children to be born to these survivors is for the immediate future too small to yield insightful findings on the basis of the conventional genetic approaches, but the emerging DNA technologies for the study of mutation (reviewed in Neel et al., 1993) hold great promise for extracting a significant body of information from each subject.

3. The requirements for successful germ-line therapy. Anderson (1985, 1992) and Davis (1992), among others, have succinctly laid down two technical advances which must occur prior to serious consideration of germ-line therapy. The shotgun introduction of genes into transgenic mice is accompanied in about $10 \%$ of "successes" by the induction of unanticipated genetic effects (Palmiter and Brewster, 1986). This is unacceptable for humans. For human germ-line therapy to be acceptable, (i) the defective gene must be replaced by precise homologous recombination and function appropriately, and (ii) there must be evidence that a new genetic problem has not been created elsewhere in the genome, presumably by nonhomologous recombination. The necessary preliminary assurances on both these points must be pursued in an experimental organism, presumably the mouse, where the extensive body of background genetic data should facilitate the large-scale search for nontargeted events that the problem requires. Even in the mouse, meeting these requirements will not be easy, since some of the possible untoward effects, such as impairment of brain functions, may be quite subtle in a mouse (but not so subtle in a human). Furthermore, the careful study of the germ-line consequences (if any) of somatic cell therapy in experimental animals, mentioned in the last section, will also fill this gap in knowledge. It is impossible to predict a time table for these developments.

The desire to ameliorate the lot of humankind through both somatic cell and germ-line therapy is the most recent extension of a healing ethic applauded through the centuries. There is an enormous amount of experimental work to be done to place this, the most recent development, in perspective. To me, as a population geneticist, germ-line gene therapy represents the ultimate in the manipulation of the biological order. Let's for once take our time.

\section{ACKNOWLEDGMENT}

I am indebted to Dr. Gary Nabel and Dr. Bernard Davis for several helpful suggestions.

\section{REFERENCES}

ANDERSON, W.F. (1985). Human gene therapy: Scientific and ethical considerations. J. Med. Philos. 10, 275-291.

ANDERSON, W.F. (1992). Uses and abuses of human gene transfer. Hum. Gene Ther. 3, 1-2.

CORNETTA, K., MORGAN, R.A., and ANDERSON, W.F. (1991). Safety issues related to retroviral-mediated gene transfer in humans. Hum. Gene Ther. 2, 5-14.

DAVIS, B.D. (1992). Germ-line therapy: Evolutionary and moral considerations. Hum. Gene Ther. 3, 361-363.

NABEL, E.G., GORDON, D., YANG, Z.-Y., LING, X., SAN, H., PLAUTZ, G.E., WU, B.-Y., GAO, X., HUANG, L., and NABEL, G.J. Gene transfer in vivo with DNA-liposome complexes: Lack of autoimmunity and gonadal localization. Hum. Gene Ther. (in press). NEEL, J.V., SATOH, C., and MYERS, R. (1993). Report of a workshop on the application of molecular genetics to the study of mutation in the children of atomic bomb survivors. Mut. Res. 291, 1-20.

PALMITER, R.D., and BREWSTER, R.L. (1986). Germ-line transformation of mice. Annu. Rev. Genet. 20, 465-499.

James V. Neel University of Michigan Medical School Medical Science II M4708 Ann Arbor, MI 48109-0618 


\section{This article has been cited by:}

1. Eric T. Juengst. 1995. "Prevention" and the Goals of Genetic Medicine"Prevention" and the Goals of Genetic Medicine. Human Gene Therapy 6:12, 1595-1605. [Abstract] [PDF] [PDF Plus]

2. Erik Parens. 1995. Should We Hold the (Germ) Line?. The Journal of Law, Medicine \& Ethics 23:2, 173-176. [CrossRef]

3. Darryl R. J. Macer, Shiro Akiyama, Angeles Tan Alora, Yukiko Asada, Jayapaul Azariah, Hilda Azariah, Maureen V. Boost, Prasert Chatwachirawong, Yuko Kato, Vijay Kaushik, Frank J. Leavitt, Nobuko Y. Macer, Chin Choon Ong, Peerasak Srinives, Miho Tsuzuki. 1995. International Perceptions and Approval of Gene TherapyInternational Perceptions and Approval of Gene Therapy. Human Gene Therapy 6:6, 791-803. [Abstract] [PDF] [PDF Plus]

4. John C. Fletcher. 1995. Gene therapy in mental retardation: Ethical considerations. Mental Retardation and Developmental Disabilities Research Reviews 1:1, 7-13. [CrossRef] 